\title{
Teaching with Literature: The Needs of Indonesian Islamic Universities
}

Dedi Irwansyah ${ }^{1 *}$, Burhan Nurgiyantoro ${ }^{2}$, Asruddin B. Tou ${ }^{2}$

${ }^{1}$ Postgraduate School of Yogyakarta State University, Indonesia

${ }^{2}$ Yogyakarta State University, Indonesia

Corresponding Author: Dedi Irwansyah, E-mail: dedi.irwansyah@student.uny.ac.id

\section{ARTICLE INFO}

\section{Article history}

Received: July 07, 2017

Accepted: August 18, 2017

Published: December 01, 2017

Volume: 6 Issue: 7

Special Issue on Language \& Literature Advance access: September 2017

Conflicts of interest: Non

Funding: None

\begin{abstract}
Reading literary works helps learners grow linguistically, personally, culturally, and spiritually. However, researchers in the field of ESL and EFL have not conducted adequate analysis on the use of literature as a resource particularly in a multi-layered educational contexts like Indonesian Islamic universities where values embedded in literature might be in conflict with each other. This research therefore aims to provide a thick description on the target needs and the learning needs of teaching with literature in such context. A case study with qualitative and quantitative methods of data collection was conducted. A questioner was distributed to 30 students and a semi-structured interview was conducted to five lecturers from three Islamic universities. Major findings show that short stories with the topics of noble character, self-empowerment, freedom, code of conduct, and greed are preferable to novel, drama, and poem. The stories in the forms of their simplified and original versions should be used to teach language skills and to inculcate global, national, and Islamic values within the CTL framework. Values similarities are to be the basis of teaching universal values while their differences are to strengthen cross-culture understanding.
\end{abstract}

Key words: Teaching with Literature, EFL, Indonesian Islamic University, Reading

\section{INTRODUCTION}

In the last decades, there has been a wide interest in how to use literature with the English language teaching (ELT) because it is beneficial to students' linguistic competence, intellectual capacity, social awareness, and cultural understanding. Literature is promising learning materials as it possesses spectacular features (Khatib, et al., 2011: 207); is a natural resource (Chalikendy, 2015: 233); is the primary materials for a communicative language teaching (Mohammad, et al., 2012: 36); and promotes creative skills (Choudhary, 2016: 1). Thus, literature deserves a place in the context of English as a Second Language (ESL) and English as a Foreign Language (EFL) seeking to develop communicative competence and character education.

Researches have shown that many factors should be considered in teaching of literature in ESL and EFL contexts, such as cultural and historical relevance (Llach, 2007: 16), integrated approach (Yimwilai, 2015: 14; Al-Mahrooqi, 2012: 179), eclectic approach (Hwang and Embi, 2007:1; Rashid, et al., 2010: 95; Areqi, 2015: 9), wide range of topics (Adelabu \& Matthias, 2013: 857), classroom activities (Yeasmin, et al., 2011: 283; Chen, 2014: 232), model of presentation (Kirgöz, 2012: 115), cultural negotiation and interaction (Bacha, 2010: 62), literary theory (Chun, 2015: 734), analysis on students' needs (Violetta-Irene, 2015: 78; Hişmanoğlu, 2005: 65), language proficiency (Hussein, et al., 2016: 136), communicative competence (Muhammed, 2013: 35), technology or ICT (Hayati \& Hashemy, 2013: 183; Li, 2011: 245; Zainal, 2012: 237; Jain, 2012: 53), assessment or testing (Khalid, 2016: 26; Mohamed, 2015: 2317; Nurgiyantoro \& Efendi, 2013: 382), curriculum (Njagi \& Muriungi, 2014: 147; Samuel, 1995: 107; Tuncer \& Kizildağ, 2014: 181), post-colonial context (Makhdoom, 2014: 420; Rohmah, 2012: 157), teacher's competency (Mills, 2011: 76; Ortells, 2013: 97), non-native writer of literary work (Mujumdar, 2010: 210), the $21^{\text {st }}$ century education context (Akhter, 2013: 7; Yeasmin, 2011: 10), cultural and linguistic differences (Shakfa, 2012: 95), literary text selection (Novianti, 2016: 45), and genres like short story (Erkaya, 2003: 10; Midhin, 2015: 83) song (Kennedy, 2014: 295) as well as poetry (Mittal, 2014: 21).

The rich body of related researches in the field convinces that literature is pedagogically, linguistically and culturally advantageous. However, less attention has been paid to its use to teach English in Indonesian Islamic university, a particular institutional context whose tradition and education philosophy, to certain extent, is different from those of the Western's. Diallo (2012: 175) argues that differences between Islamic tradition and Western tradition bring about divergent pedagogical and epistemological implications. Rohmah (2012: 157) argues that the failure of bridging the two traditions might create tension among learners. Thus, 
within Indonesian context, English materials should include Islamic messages. Meanwhile, Adebayo (2010: 198) reports that European publishers sometimes present EFL texts and illustrations which are insensitive to Islamic idioms or symbols. The same is true with the Islamic symbols used in $A$ Thief's Story which seems insensitif for English learners at Indonesian Islamic unversity (see Kasser and Silverman, 1986: 102-103). Thus, an investigation on what the learners and teachers expect from reading literature should be conducted. Only then can literature be used to foster the growth of students' heart, head, and hand.

The present study will fill in the gab by investigating the target needs and the learning needs of teaching with literature in the English Department of Islamic Universities. The aims of the study are formulated into the following research questions:

1. What are the students' target needs and the learning needs of teaching English with literature?

2. What are the teachers' target needs and the learning needs of teaching English with literature?

The findings of this research will shed some light on designing appropriate literature-based reading model for students of the English Department at Islamic universities within Indonesian context.

\section{LITERATURE REVIEW}

\section{Literature and EFL}

Stern (1991: 330-337) holds that literature could be integrated with the mastery of language (vocabulary and grammar) and with the language skills (listening, speaking, reading, and writing). It serves as a good context to teach idioms, culture-tied words and phrases, and grammatical structures; helps learners build literal understanding, inferential skill, and evaluation skill; provides a model for writing activities; and serves as a basis for oral activities through role playing and oral reading. Nevertheless, it is not always easy to identify which text constitutes literary and which one non-literary. Although specific features like intertextuality and foregrounding language often characterize a literary text, those features are relative rather than absolute since fi urative languages like metaphors and similes often occur in everyday colloquial conversation (Lazar, 2009: 7). For the purpose of this study, the term literature refers to poetry, song, fiction, drama, essay, and biography, philosophical and religious texts (Maley, 2012: 302). When it is hard to categorize whether a text is literary or non-literary, a teacher should ask himself or herself whether the text is linguistically, culturally, and spiritually 'sweet and useful' (dulce et utile) for the students or not.

The use of literature in language classroom has been faced with two main approaches. First, 'literature as study' aims at teaching about literature or the knowledge of literature in order to gain qualification in literary study (Maley, 2012: 303). Synonymous to this approach are: traditional approach (Hall, 2005: 49), literature as content (Lazar, 2009: 24), and teaching literature as literature (Carter and McRae, 1996: xxiii). These approaches emphasize the study of canon works, the writer's biography and influences, stylistic study, literary critic, moral agenda historical and socio-cultural information about the text. The proponents of these approaches view a literary text as sacrosanct in that it should not be altered grammatically, extended, or cut up. In other words, literary text should not be adapted or simplified

Second, 'literature as resource' centers upon the notion of teaching with literature in that literary texts are used as springboards to engage with other language learning activities (Maley, 2012: 303). Other related terms include: communicative language teaching approach (Hall, 2005: 49), language-based approach (Lazar, 2009: 23), and teaching literature as language (Carter and McRae, 1996: xxii). This approach implies that a literary text should not be treated differently from other texts so that it be cut up or adapted to suit the instruction goals.

Cox (2012: 2-3) states that literature includes efferent reading and aesthetic reading in that readers will explore the information of the text and associate it with their feelings, attitudes, and experiences. Treating a literary text as just another text without linking it with students feelings and experiences might not be appropriate. Yet, exposing stylistic and socio-cultural aspects of the work to less proficient students is not wise. Hence, this paper uses the term 'teaching with literature' to denote the teaching of linguistic elements prior to the values embedded in the work. Teachers might want to expose central vocabularies and certain grammatical points before asking the students to respond idea, message, morals, and values of the text

\section{Models of Teaching Literature}

The fundamental question of why teaching literature has led to theories on three models of teaching literature: the cultural model, the language model, and the personal model (Carter and Long, 1991: 2-10). First, the cultural model treats as a source of information about the target culture and aims at appreciating different cultures and ideologies. Rashid, et al., (2010: 89-90) point out that the cultural model is a traditional approach of teaching literature since the teacher's role is to pass knowledge about the text while students' roles are to discover the social, political, and historical context of the given text.

Second, the language model uses literature as an instrument to mainly teach the linguistic forms or features. Bibby and Mcllroy (2013: 19-20) maintain that the model tends to be more psycholinguistic since it focuses on how language is used within the given text. Third, the personal growth model is rooted in the idea of helping the students to read and engage with the literary text by relating the themes of the text to the students' personal experiences. Violetta-Irene (2015: 75-76) notes that the model is to help students grow and mature individually and socially.

This study mainly uses the language model as the steppingstone to teaching literature. Cultural issues and personal experience are emphasized when students have been adequately exposed to linguistic features. Thus, the cultural model and the personal growth model are used in addition to the language model so as not to make a literary text just 
as another text. As such, a literary text helps students grow linguistically, personally, culturally, and spiritually.

\section{Indonesian Islamic University: A Particular ELT Context}

While Moslems constitute a large number of ESL and EFL learners all over the world in that English expressions related to Islam have been included into a comprehensive English dictionary (Ali, 2007: 32), Indonesian Islamic university is one of the settings where a vast number of Moslem students learn English. The university is particular since it is built upon three pillars: Islamic faith (aqidah), worldly matters (muamalah), and Islamic morals (akhlaqul karimah) (Muhadjir, 2011: 309). It is that vast number of learners and the particularity of the educational setting that make Indonesian Islamic university deserves ELT practitioners.

Islamic university is pedagogically and epistemologically attached to Qur'anic revelation, prophetic tradition (Sunna and Hadith), and the opinion of the righteous predecessors (qawl al-salaf al-salih) (Diallo, 2012: 175). It places the spirits of Qur'anic revelation and Prophetic precedent as the heart of education and the glue of the entire curriculum (Halstead, 2005: 525). Such pillars and principles are supposed to shed a light on the EFL goals, syllabus, and classroom activities of any Islamic university.

It is in the above context that an investigation on the needs of Indonesian Islamic university is of a real significance. By the needs we mean the target needs and the learning needs. The former refers to what the students need to do in the target situation. It is pertinent to what is necessary for students to learn (necessities); what aspects of the subject that the students lack of (lacks); and what the students want to learn (wants). The latter deals with what the students need to do in order to make learning happen (Nation \& Macalister, 2010: 24-25). It covers the analysis on goals, input, setting, procedure, teacher's roles, learners' roles and so forth.

\section{METHODS}

\section{Participants}

A total number of 5 lecturers and 95 students of Indonesian Islamic universities participated in this study. The lecturers participated in the interview phase were lecturers of English Language Education Department at Islamic universities: two from Muhammadiyah University of Metro (MUM), one from Ma'arif Islamic Institute NU of Metro (MIINM), and two from State Islamic Institute of Metro (SIIM), Indonesia. While the students involved in the questionnaire phase were the second year students of English Language EducationDepartment of SIIM. All partipants involved in the research were from the Province of Lampung, Indonesia.

\section{Instrumentation}

Two instruments were used to collect the data: an interview and a questionnaire. The semi-structured interview consisted of 12 items. The questions were pertinent to the target needs (necessities, lacks, wants) and learning needs (goals, input, procedure, learners' role) of teaching with literature at Indonesian Islamic universities.

The questionnaire consisted of 41 items in the form of a four-point Likert-scale. The items covered topics of the literary text, text comprehension level, forms of literary works, goals of instruction, text source, text version, text length, materials distribution, and students' expectation of teacher's role. The items were conceptually validated by experts in the field of reading instruction and literature teaching

\section{Procedure}

A case study was used as an approach to elicit the perspectives of the involved participants (Gall, et al, 2007: 447). Although it was basically a qualitative research, it applied a quantitative method in valitdating the instruments and displaying the data. This case study design included five steps. First, the items of the interview and questionnaire were validated by experts in the field. Second, the interview was administered to five English lecturers to gain qualitative data. The lecturers are representatives of state Islamic university, private Islamic university affiliated with Nahdhatul Ulama organization, and private Islamic university affiliated with Muhammadiyah organization. Third, the qualitative data and interpretations were validated through member checking technique in that the researcher asked one of the participants to check the accuracy of the interview description. Fourth, the questionnaire was piloted to 65 students to ensure its reliability and validity. Cronbach's alpha was calculated to be 0.805 . Fifth, the reliable questionnaire was distributed to other 30 students to gain quantitative data. Quantitative analysis was used to support the interpretation of the qualitative findings

\section{FINDING AND DISCUSSION}

In general, it is found that the use of short stories with rich topics is more preferable than that of poem, novel, and drama. The short stories are expected to be a vehicle to teach micro-skills and macro-skills of reading as well as a springboard to explore global, national, and Islamic culture. Meanwhile, the topics, which ranges from noble character to greed, are to be related with Islamic values. The rest remarkable finding will be discussed further in the following section.

\section{The Students' Target Needs and the Learning Needs of Teaching English with Literature}

The data on students' perspectives related to the sub-items of the target needs (necessities, lacks, wants) and the learning needs (goals, input, setting, and teacher's role) are ranked in order to gain a general description. The results from the ranking are presented in the Table 1.

The elaboration of each sub-item is further presented in the form of rating tables so as to provide a richer description.

\section{Target needs}

For this research, target needs is directed at gathering information about: (1) necessities which is mainly about the top- 
Table 1. The rank of sub-items of students' needs analysis

\begin{tabular}{|c|c|c|c|c|}
\hline No. & Question substance & Sub-item & Rank & Mean \\
\hline & Target needs & & & \\
\hline \multirow[t]{4}{*}{1.} & Topics of the literary text & Noble character & I & 3.73 \\
\hline & & Self-empowerment & II & 3.43 \\
\hline & & Human and society & III & 3.33 \\
\hline & & Environment & IV & 3.07 \\
\hline \multirow[t]{8}{*}{2.} & Text comprehension level & Friendship & I & 3.63 \\
\hline & & Peace & II & 3.23 \\
\hline & & Heroism & III & 2.97 \\
\hline & & Bravery & IV & 2.93 \\
\hline & & Love & $\mathrm{V}$ & 2.90 \\
\hline & & Freedom & VI & 2.80 \\
\hline & & Code of conduct & VII & 2.73 \\
\hline & & Greed & VIII & 2.07 \\
\hline \multirow[t]{4}{*}{3.} & Forms of literary works & Short story & $\mathrm{I}$ & 3.50 \\
\hline & & Drama & II & 3.37 \\
\hline & & Novel & III & 3.17 \\
\hline & Learning needs & & & \\
\hline \multirow[t]{6}{*}{4.} & The goals of instruction & Reading strategies & I & 3.67 \\
\hline & & Comprehension & II & 3.60 \\
\hline & & Vocabulary and grammar & III & 3.57 \\
\hline & & Reading speed & IV & 3.53 \\
\hline & & Values & $\mathrm{V}$ & 3.40 \\
\hline & & Cohesion devices & VI & 3.20 \\
\hline \multirow[t]{3}{*}{5.} & Text source & Inner circle countries & I & 3.53 \\
\hline & & Outer circle countries & II & 2.23 \\
\hline & & Expanding circle countries (suggestion) & III & 0.17 \\
\hline \multirow[t]{2}{*}{6.} & Text version & Simplified & I & 3.47 \\
\hline & & Original & II & 2.83 \\
\hline \multirow[t]{3}{*}{7.} & Text length & $1-2$ pages & I & 3.20 \\
\hline & & 5-6 pages & II & 2.97 \\
\hline & & $>6$ pages & III & 2.23 \\
\hline \multirow[t]{2}{*}{8.} & Materials distribution & Weekly & I & 3.07 \\
\hline & & All in the first meeting & II & 2.90 \\
\hline \multirow[t]{8}{*}{9.} & Students' expectation of the teacher's role & Role model & $\mathrm{I}$ & 3.73 \\
\hline & & Resource developer & II & 3.53 \\
\hline & & Information provider & III & 3.50 \\
\hline & & Facilitator & III & 3.50 \\
\hline & & Assessor & III & 3.50 \\
\hline & & Planner & IV & 3.40 \\
\hline & & Participant & IV & 3.40 \\
\hline & & Manager & $\mathrm{V}$ & 3.37 \\
\hline
\end{tabular}

ics to be presented through the literary texts; (2) lacks that is particularly pertinent to the students' understanding level on certain topics; and (3) wants which is related to the forms of literary works that the students need to read. The results from this research are presented in the tables below.

Table 2. shows the topics of the literary texts that students wish to read. More than half of students rated noble charac- ter as absolutely necessary (73.3\%), and self-empowerment as necessary topics (56.7\%). Findings also reveal that few students think that the topics on human and society as well as environment are unnecessary. It is likely due to the rare exposure to the last two topics mentioned.

Table 3. is related to the students' self-assessment of their understanding on particular topics. A majority of respon- 
dents $(66.7 \%)$ comprehend the texts on friendship. More than half of the students are good at understanding the topics on heroism (50\%), peace (56.7\%), and love (56.7\%). Half of them are good at texts on heroism $(50 \%)$ and bravery $(50 \%)$. The students' understanding on freedom, code of conduct, and greed appear to be low which implies the need to include more texts on the mentioned topics. Khairuddin, et al. (2014: 128-129) report that Muslim Malaysian undergraduate students tend to read texts about personal relationship, Islamic studies like Qur'an and Prophet's tradition, and personal development like motivation and seeking knowledge.

Table 4. shows the percentage of what literary works that the students wanted to read in the Reading class. It appears that short story was the most wanted form as none of the respondents perceived it as unnecessary. However, drama and novel were also welcome.

\section{Learning needs}

The learning needs is aimed at collecting relevant information on: (1) goals or the things that the students ought to learn in a Reading class; (2) inputs which cover the cultural background of the texts, the version of the texts, and the length of the texts; (3) setting which mainly deals with the material distribution preferred by the students; and (4) teach- er's role or the activities that the students want from a lecturer of reading. The results from this research are presented in Table 5.

Tabel 5. shows what the respondents prefer to learn in a Reading class. More than half of the students strongly agree to learn reading strategies $(66.7 \%)$, reading comprehension $(60 \%)$, vocabulary and grammar $(56.7 \%)$, and reading speed (56.7\%). More than half agree to learn values $(60 \%)$ and cohesion devices (73.3\%). Interestingly, all respondents agreed to include values in addition to reading microskills and macroskills.

Table 6. presents the the cultural backround of the texts that the respondents wanted to read. All of the respondents agree $(46.7 \%)$ and strongly agree (53.3) to read the texts from British and American culture. Most of the respondents disagree $(60 \%)$ with reading texts from outer cirle countries like India and Singapore. Some respondents suggested that the texts be taken from Korean, Japanese, Middle East, and Indonesian cultural background.

Table 7. shows that the respondents prefer to read simplified version of the literary work, $43.3 \%$ agree and $36.7 \%$ disagree. However, although $36.7 \%$ of the respondents disagree with reading the original version, the rest $63.3 \%$ stated that they wish to read the original ones. This indicates that both simplified and original versions of the texts could be included.

Table 2. Necessities: Ratings according to the topics of the literary text

\begin{tabular}{llcccc}
\hline \multirow{2}{*}{ Rank } & Topics of the literary text & \multicolumn{4}{c}{ Percentage } \\
\cline { 3 - 6 } & & Totally unnecessary & Unnecessary & Necessary & Absolutely necessary \\
\hline I & Noble character & - & - & 26.7 & 73.3 \\
II & Self-empowerment & - & - & 56.7 & 43.3 \\
III & Human and society & - & 13.3 & 40 & 46.7 \\
IV & Environment & 3.3 & 20 & 43.3 & 33.3 \\
\hline
\end{tabular}

Table 3. Lacks: Ratings according to text comprehension level

\begin{tabular}{llcccr}
\hline Rank & Text comprehension level & \multicolumn{3}{c}{ Percentage } \\
\cline { 3 - 6 } & & Poor & Enough & Good & Excellent \\
\hline I & Friendship & - & 3.3 & 30 & 66.7 \\
II & Peace & - & 10 & 56.7 & 33.3 \\
III & Heroism & 6.7 & 16.7 & 50 & 26.7 \\
IV & Bravery & 3.3 & 23.3 & 50 & 23.3 \\
V & Love & 6.7 & 16.7 & 56.7 & 20 \\
VI & Freedom & 3.3 & 33.3 & 43.3 & 20 \\
VII & Code of conduct & 13.3 & 23.3 & 40 & 23.3 \\
VIII & Greed & 33.3 & 30 & 33.3 & 3.3 \\
\hline
\end{tabular}

Table 4. Wants: Ratings according to the forms of the literary works

\begin{tabular}{llcccc}
\hline Rank & The forms of literary works & \multicolumn{4}{c}{ Percentage } \\
\cline { 3 - 6 } & & Totally unnecessary & Unnecessary & Necessary & Absolutely necessary \\
\hline I & Short story & - & - & 50 & 50 \\
II & Drama & - & 6.7 & 50 & 43.3 \\
III & Novel & - & 6.7 & 70 & 23.3 \\
\hline
\end{tabular}


The use of simplified and original literary works has been o served by Khanum (2016: 43) in the context of literature-based materials in Bangladesh, where he noticed that 'in case of using original form of literature simplified versions should be used.' Zhen (2012: 38) also reports that in the EFL context in China, exposing original texts without their simplified versions are not suitable for students with limited command of English. Thus, both simplified version of literary work can be used as a springboard for appreciating the original version.

Tabel 8. shows that the majority of the students have positive attitude toward reading 1 to 6 pages. The text length of more than 6 pages was disagreed by around $66.7 \%$ of the respondents.
Tabel 9. is related to the reading materials distribution. $26.7 \%$ disagree with perceiving the materials weekly, while $36.6 \%$ (strongly) disagree with perceiving them all in the first meeting. $73.3 \%$ would like to perceive the materials weekly, and $63.3 \%$ all in the first meeting

Tabel 10. shows a list of the most wanted roles that the respondents want their lecturers to play, consecutively: role model, resource developer, information provider, facilitator, assessor, planner, participant, and manager. However, few students do not expect the teacher's role as facilitator $(3.3 \%)$, assessor (6.7\%), and manager (3.3\%).

In sum, the findings of the target needs gathered from the questionnaire imply that short stories about noble charac-

Table 5. Goals: Ratings according to the goals of instruction

\begin{tabular}{llcccc}
\hline \multirow{2}{*}{ Rank } & The goals of instruction & \multicolumn{3}{c}{ Percentage } \\
\cline { 3 - 6 } & & Strongly disagree & Disagree & Agree & Strongly agree \\
\hline I & Reading strategies & - & - & 33.3 & 66.7 \\
II & Comprehension & - & - & 40 & 60 \\
III & Vocabulary and grammar & - & - & 43.3 & 56.7 \\
IV & Reading speed & - & 3.3 & 40 & 56.7 \\
V & Values & - & - & 60 & 40 \\
VI & Cohesion devices & - & 3.3 & 73.3 & 23.3 \\
\hline
\end{tabular}

Table 6. Input: Ratings according to the text source

\begin{tabular}{llcccc}
\hline Rank & The text source & \multicolumn{3}{c}{ Percentage } \\
\cline { 3 - 5 } & & Strongly disagree & Disagree & Agree & Strongly agree \\
\hline I & Inner circle countries & - & - & 46.7 & 53.3 \\
II & Outer circle countries & 10 & 60 & 26.7 & 3.3 \\
III & Expanding circle countries* & & & \\
\hline
\end{tabular}

*Respondents' suggestion

Table 7. Input: Ratings according to the text version

\begin{tabular}{llcccr}
\hline \multirow{2}{*}{ Rank } & The text version & \multicolumn{4}{c}{ Percentage } \\
\cline { 3 - 6 } & & Strongly disagree & Disagree & Agree & Strongly agree \\
\hline I & Simplified & 3.3 & - & 43.3 & 53.3 \\
II & Original & - & 36.7 & 43.3 & 20 \\
\hline
\end{tabular}

Table 8. Input: Ratings according to the text length

\begin{tabular}{llcccc}
\multirow{2}{*}{ Rank } & The text length & \multicolumn{4}{c}{ Percentage } \\
\cline { 3 - 6 } & & Strongly disagree & Disagree & Agree & Strongly agree \\
\hline I & $1-2$ pages & - & 16.7 & 46.7 & 36.7 \\
II & $5-6$ pages & - & 26.7 & 50 & 23.3 \\
III & $>6$ pages & 16.7 & 50 & 26.7 & 6.7 \\
\hline
\end{tabular}

Table 9. Setting: Ratings according to materials distribution

\begin{tabular}{llcccr}
\cline { 3 - 6 } Rank & Materials distribution & \multicolumn{4}{c}{ Percentage } \\
\cline { 3 - 6 } & & Strongly disagree & Disagree & Agree & Strongly agree \\
\hline I & Weekly & - & 26.7 & 40 & 33.3 \\
II & All in the first meetin & 3.3 & 33.3 & 33.3 & 30 \\
\hline
\end{tabular}


Table 10. Teacher's roles: Rating according to students' expectation of the teacher's roles

\begin{tabular}{llccccc}
\hline Rank & Text comprehension level & & \multicolumn{2}{c}{ Percentage } & \\
\cline { 3 - 5 } \cline { 5 - 6 } & & Strongly disagree & Disagree & Agree & Strongly agree \\
\hline I & Role model & - & - & 26.7 & 73.3 \\
II & Resource developer & - & - & 46.7 & 53.3 \\
III & Information provider & - & - & 50 & 50 \\
III & Facilitator & - & 3.3 & 43.3 & 53.3 \\
III & Assessor & - & 6.7 & 36.7 & 56.7 \\
IV & Planner & - & - & 60 & 40 \\
IV & Participant & - & - & 60 & 40 \\
V & Manager & - & 3.3 & 56.7 & 40 \\
\hline
\end{tabular}

ter, self-empowerment, freedom, code of conduct, and greed are mostly needed. Meanwhile, the findings of the learning needs imply that reading class should include micro-skills, macro-skills, and values. Both simplified and original texts with the length range of 1-6 pages are needed. Reading lecturers are expected to be role models and resource developers at most.

\section{The Teachers' Target Needs and the Learning Needs of Teaching English with Literature}

All the interviewees are reading lecturers except one from SIIM who is a senior lecturer and a curriculum developer. As the subjects of the research, the lecturers were coded into S1, S2, S3, S4, and S5. The interview was conducted during October, 2016. The questions of the semi-structured interview were related to the target needs and learning needs. The findings of the the interview are displayed in tables below.

Table 11. shows that all respondents agree to integrate the Islamic values of faith, wordly matters, and morals into the reading materials. A reading text should be utilized to improve students' intellectual, social, and spiritual domains as well as environmental awareness. The text is to be connected with Muhadjir's (2011: 309) terms of 'three pillars of Islamic university'; Diallo's (2012: 175) notion of Islamic pedagogy and epistemology; and Halstead's (2005: 525) opinion on Islamic concept of education which is based on the Qur'anic revelation and Prophetic tradition. Thus, the values underpinned the developed model should be derived from Qur'anic verse, prophetic tradition, and the opinion of the righteous Muslim scholars. The values are believed to be universal as Islam is mercy for all creatures (rahmatan lil 'aalamin).

Table 12. is related to the topics which are either easy or difficult for the students. Most lecturers found the topics related to daily lives (love, friendship, religion) tend to be easier than those to science and medicine. The stories from prophetic tradition were easy to understand as the students had possessed the relevant schemata of the stories. However, a religious text with Islamic technical terms are not always easy to understand for their English equivalence are not always available in English dictionary. To cope with this, glosses or the explanation difficult words or phrases should be interestingly added to the reading text to help students with difficult topics
Table 11. The necessities

\begin{tabular}{l}
\hline Target needs \\
\hline Necessities \\
The pillars of an Islamic university (tauhid, muamalah, and \\
akhlakul karimah) should be integrated into the reading \\
materials (S1- S5) \\
The topics in reading class should help students grow \\
personally (S1-S5); socially (S3); intellectually (S4), and \\
spiritually (S3, S4) \\
The topics should also make the students aware of the \\
environmental issues (S1-S5) \\
Reading texts ought to be connected with the verses in the \\
Holy Qur'an (S4)
\end{tabular}

Table 12. The lacks

\begin{tabular}{l}
\hline Target needs \\
\hline Lacks \\
Most students deal positively with the topics on: current \\
phenomena (S1); love (S1, S2, S3); friendship (S2, S3); daily \\
lives (S3); the story of the prophets (S4); and the story of the \\
companions (S4) \\
Most students find it difficult to understand scientific \\
articles (S1, S2, S4), journals (S1), medical texts (S3) \\
English texts with specific Islamic terms tend to be harder than \\
scientific texts. Mostl, the terms are not available in English \\
dictionary (S5)
\end{tabular}

Table 13. is related to the feasibility of using poem, novel, drama, and short story in a Reading class. Despite the fact that all forms of literary work are usable, short story is the most plausible for it suits the time allotment of reading activity in the class. It could belong to shorter text that fits fits in-class reading and supports in class-discussion. However, a short story could be complicated in term of language and message in that it needs to be adapted to fit the students' language proficiency and intellectual capacit .

Table 14. shows the learning needs, particularly the goals of teaching reading. The respondents agree that a reading class should go beyond micro-skills of reading (word, sentence, cohesive device) and macro-skills of reading (inference, guessing meaning, activating schemata, applying read- 
Table 13. The wants

\begin{tabular}{l}
\hline Target needs \\
\hline Wants \\
Drama (S1, S2, S5); poem (S3), novel (S1, S3); and short \\
story (S1, S2, S3, S4, S5) could be used in Reading class \\
Of the feasible genres, short story best fits the time allocation \\
of the reading class (S3) \\
The reading of literary texts followed by role-play or 'acting it \\
out' activity is preferable (S2)
\end{tabular}

Table 14. The goals

\begin{tabular}{l}
\hline Learning needs \\
\hline Goals \\
In addition to vocabulary and grammar, the moral lessons (S1, \\
S3) and religious values (S2, S3, S4) of the reading text should \\
be emphasizhed \\
Lesson plan should include related religious values as the goal \\
of the Reading class (S2) \\
Reading comprehension levels (S3) and reading strategies (S3, \\
S5) are skills to stated as the goals of the Reading class
\end{tabular}

ing strategies). The class should be a medium of inculcating religious values. A study conducted by Rohmah (2012: 164) reports that teachers and students in Indonesian Islamic schools 'are in need for English materials with some Islamic messages.' Thus, English learning will be more meaningful when it accommodates students' spiritual domain.

Table 15. is pertinent to the questions on text source, version, and length. All respondents include Islamic world as the source of the reading texts in addition to inner circle countries, outer circle countries, and expanding circle countries. A study by Makhdoom (2014: 420) reports that the use of various sources will encourage the teachers to include indigenous literature so as to reduce the hegemony of the western literary text. Qiping \& Shubo (2002: 323) also report that texts from the students' cultural background and other cultures areto be designed within the framework of CTL so that the students would connect the text with their personal, social, and cultural contexts. Literary texts that are linked with students' memories, feelings, and imagination will amplify educational, cultural, and even economic values.

With regard to the text version and length, it seems that most respondents agree to utilize both simplified and original versions. While the text length range from 1-6, most respondents suggest 1-2 pages. It is safe to state that 2-4 pages will be a moderately suitable text length.

Table 16. is related to the efforts that a lecturer should make for an effective literature reading class. The efforts could be broadly categorized into planning, implementing, and evaluating. The planning stage includes: stating instructional goals; developing learning materials, planning student-centered classroom scenario; designing classroom activities. The implementing stage covers: activating prior knowledge, providing relevant information, and modelling activities. The evaluation stage embraces assessing reading skills.
Table 15. The inputs

\begin{tabular}{l}
\hline Learning needs \\
Inputs \\
The source of the texts could be inner circle countries (S1, S2, \\
S3, S5), outer circle countries (2), expanding circle countries \\
mainly Indonesia (S1, S2, S3), and Islamic literature (S1, S2 \\
S3, S4, S5) \\
The reading texts should be selected on the framework of \\
Contextual Teaching Learning (CTL) (S2) \\
Both simplified and original texts could be used (S1, S2, S3, \\
S5) \\
Simplified text is preferable (S4) \\
The text length could be 1-2 pages (S2, S3, S4), 3-5 \\
pages (S5), 5-6 pages (S1)
\end{tabular}

Table 16. The procedure

\section{Learning needs}

Procedure

Lecturer should help the students gain their fullest potential of reading (S3)

Lecturer should develop a relevant learning materials (S3)

Lecturer should plan an intersting, engaging, and student-centered classroom scenario (S3, S4)

Lecturer should manage group assignment and peer teaching scheme (S4)

Lecturer should activate the students' prior knowledge (S1)

Lecturer should provide information that helps students bridge the content of the text with their personal, social, and spiritual life (S1, S2)

Lecturer should model the students through reading aloud and paraprashing activities (S5)

Lecturer should assess the students' active participation during the class (S3)

Table 17. The learners' role

\begin{tabular}{l}
\hline Learning needs \\
\hline Learners' role \\
Students should build a good reading habit by dealing \\
with various texts (S1, S2, S3) and accomplishing reading \\
homework (S1) \\
Students should develop their scanning skill, skimming skill, \\
and reading speed skill (S2) \\
Students should be able to work in team, solve problem raising \\
from the text, and tutor their peers
\end{tabular}

Table 17. shows the lecturers' expectation on the students' roles. The students are hoped to be independent learners, active participants, problem solvers, peer tutors, and team workers. These roles would improve the students' reading skills and help form good reading habit.

In sum, the findings of the target needs gathered from the interview imply that the literary texts incorporate Islamic values emphasizing noble characters. The materials, mostly needed in the form of short stories, need to be accompanied 
by glosses to help students with difficult words, phrases, and terms. Meanwhile, the findings of the learning needs imply that the course should go beyond teaching micro-skills and macro-skills within CTL framework. The texts ought to represent global, national, and Islamic contexts with 2-4 length average. The scheme of combining original and simplified short stories is needed. Further, proper classroom activities and tasks are needed to help the learners be independent, active participants, problem solvers, peer tutors, and team workers.

\section{CONCLUSION}

With regard to the target needs, this research showed that teaching English with literature will be effective when it utilizes short story with various topics such as noble character, self-empowerment, freedom, code of conduct, and greed. The stories should be related to Islamic values and equipped with glosses of difficult words, phrases and expressions. Meanwhile, the learning needs showed that teachers should utilize literature, both simplified and original versions, to teach micro-skills, macro-skills, and values within the framework of CTL. Besides, the texts to be used should represent global, national, and Islamic cultural backgrounds. The concluding remarks of this research will help future researcher to design a contextually-relevant learning materials and to develop a model of teaching with literature within the particular educational context of Indonesian Islamic universities.

\section{REFERENCES}

Adebayo, R.I. (2010). Islam and the promotion of mulitilingualism: lessons for the Nigerian muslims. Allawh: Journal of Arabic \& Islamic Studies, 2 (6), 183-201.

Adelabu, B. \& Matthias, N. (2013). Survey of methods of teaching English and literature among secondary school teachers in Benue State. International J. Soc. Sci. \& Education, 3 (3), 847-858.

Akhter, T. (2013). Importance of English literature teaching in $21^{\text {st }}$ century in students of higher secondaries and colleges of Anantnag district of Jammu and Kashmir. The International Journal of Engineering and Science (IJES), 2 (4), 6-8.

Ali, H.M.B.M. (2007). Islamic Terms in Contemporary English. English Today. 23 (2), 32-38. doi: 10.1017/ S0266078407002064, http://Journals.cambridge.org/ ENG.

Al-Mahrooqi, R. (2012). An investigation of literature teaching methodologies at a higher educational institution in Oman. TESOL Journal, 6 (1), 172-180.

Areqi, R.M.M.A. (2015). Teaching/testing English literature through eclectic model. International Journal on Studies in English Language and Literature (IJSELL), 3 (4), 9-21.

Bacha, N.N. (2010). Teaching literature in an English as a foreign language classroom: A study of student attitudes. The International Journal of the Humanities, 8 (1), 47-64.

Bibby, S. \& Mcllroy, T. (2013). Literature in language teaching: What, why, and how. The Language Teacher, 37 (5), 19-21.
Carter, R., \& Long, M.N. (1991). Teaching literature. New York: Longman Publishing, (Chapter I).

Carter, R., \& McRae, J. (1996). Language, literature, and the learner: Creative classroom practice. London: Addison Wesley Longman Limited, (Chapter 0, Introduction Part).

Chalikendy, M.A. (2015). Literature: a Natural Source for Teaching English in ESL/EFL Classrooms. International Journal of Applied Linguistics \& English Literature. 4 (6), 224-234. doi: 10.7575/aiac.ijalel.v.4n.6p.224, http://dx.doi.org/10.7575/aiac.ijalel.v.4n.6p.224.

Chen, M.L. (2014). Teaching English as a Foreign Language through Literature. Theory and Practice in Language Studies. 4 (2).,232-236. doi: 10.4304/tpls.4.2.232-236.

Choudhary, S. (2016). A literary approach to teaching English language in a multicultural classroom. Higher Learning Research Communications, 6 (4), 1-6.

Chun, Y. (2015). Application of Literary Theory in Teaching Literature: a Case Study from "Approaching Fiction" in China Youth University of Political Sstudies. Sino-US English Teaching. 12 (9), 730-735. doi: 10.17265/15398072/2015.09.012.

Cox, C. (2012). Literature-based teaching in the content areas. California: SAGE Publications, Inc., (Chapter 0, Introduction Part).

Diallo, I. (2012). The interface between Islamic and western pedagogies and epistemologies: features and divergences. International Journal of Pedagogies and Learning, 7(3), 175-179.

Erkaya, O.R. (2003). Benefits of using short stories in the EFL context. Asian EFL Journal, 1-13.

Gall, M.D., Gall, J.P., \& Borg, W.R. (2007). Educational research: an introduction ( $8^{\text {th }} e d$.). Boston: Pearson Education, Inc., (Chapter (Part) IV)

Hall, G. (2005). Literature in language education. New York: Palgrave Macmillan, (Chapter II).

Halstead, J. M. (2004). An Islamic Concept of Education. Comparative Education. 40 (4), 517-528. doi: 10.1080/0305006042000284510.

Hayati, D. \& Hashemy, S.A. (2013). Communication Technologies and Virtual Learning Environment (VLE) in Teaching Literature. International Journal of Innovation, Management and Technology. 4 (2), 181-184. doi: 10.7763/IJIMT.2013.V4.387.

Hişmanoğlu, M. (2005). Teaching English through literature. Journal of Language and Linguistic Studies, 1 (1), 5366.

Hussein, E.T. \& Al-Emami, A.H. (2016). Challenges to teaching English literature at the university of Hail: instructors' perspective. Arab World English Journal (AWEJ), 7 (4), 125-138.

Hwang, D. \& Embi, M.A. (2007). Approaches employed by secondary school teachers to teaching the literature component in English. Jurnal Pendidik dan Pendidikan, $22,1-23$

Jain, M. (2012). ICT as an aid in teaching English literature and bridging the digital divide. Bhatter College Journal of Multidisciplinary Studies, Vol. II, pp. 49-54. 
Kasser, C., \& Silverman, A. (1986). Stories we brought with us: beginng readings for ESL. New Jersey: Prentice Hall, (Chapter XIV).

Kennedy, V. (2014). Critical, cultural and multimodal approaches to using song as literature in language learning. Liberi \& Liberi, 3 (2), 295-310.

Khairuddin, Z., Shukry, A.S.M., \& Sani, N.A. (2014). Reading trends and perceptions towards Islamic English websites as teaching materials. English Language Teaching. 7 (8), 124-133. doi: 10.5539/elt.v7n8p124, http://dx.doi. org/10.5539/elt.v7n8p124.

Khalid, A. (2016). Critical role of assessment in teaching English literature to non-natives. International Journal of English Literature and Culture, 4 (2), 24-31.

Khanum, F. (2016). Preference of the learners towards literature based materials in the present textbook of classes ix and $\mathrm{x}$ in Bangladesh. Language in India, 16 (12), 30-45.

Khatib, M., Rezaei, S., \& Derakhshan, A. (2011). Literature in EFL/ESL classroom. English Language Teaching, 4 (1), 201-208.

Kirgöz, Y. (2012). Incorporating short stories in English language classes. Novitas-ROYAL (Research on Youth and Language), 6 (2), 110-125.

Lazar, G. (2009). Literature and language teaching: a guide for teachers and trainers. (19 ${ }^{\text {th }}$ printing). Cambridge: Cambridge University Press, (Chapter I \& II).

Li, D. (2011). How to teach and learn English literature in e-education era. International Journal of e-Education, e-Business, e-Management and e-Learning, 1 (3), 241-245.

Llach, P.A. (2007). Teaching language through literature: The waste land in the ESL classroom. Odisea, 8, 7-17.

Makhdoom, M. (2014). Education and neo-colonization: A critique of English literature curriculum in Pakistan. A Research Journal of South Asian Studies, 29 (2), 411-421.

Maley, A. (2012). Literature and languge teaching. In Alsagoff, L., et al., (eds.), Principles and practices for teaching English as an international language (pp. 299317). New York: Routledge, (Chapter XVII).

Midhin, M.M. (2015). Techniques used by university instructors in teaching short story. International Journal of Language and Linguistics, 2 (3), 83-92.

Mills, N. (2011). Teaching Assistants' Self-Efficacy in Teaching Literature: Sources, Personal Assessments, and Consequences. The Modern Language Journal. 95 (i), 61-80. doi: 10.11111/j.1540-4781.2010.01145.x.

Mittal, R. (2014). Teaching English through poetry: A powerful medium for learning second language. IOSR Journal Of Humanities And Social Science, 19 (5), 21-23.

Mohamed, S.E.H.E. (2015). Towards effective values of teaching literature to secondary school students. International Journal of Science and Research (IJSR), 4 (11), 2317-2322.

Mohammad, Khatib, Hossein, A., \& Rahimi. (2012). Literature and language teaching. Journal of Academic and Applied Studies, 2(6), 32-38.

Muhadjir, N. (2011). Metodologi penelitian. Yogyakarta: Penerbit Rake Sarasin, (Chapter XI).
Muhammed, A.A. (2013). The effect of teaching literature on learning English language: A study on EFS (English as a foreign students) and EFL classes. International Journal of Advanced Research in Literature and Education, 1 (1), 27-38.

Mujumdar, S.A. (2010). Teaching English language and literature in non-native context. Language in India, 10 (6), 210-216

Nation, I.S.P., \& Macalister, J. (2010). Language curriculum design. New York: Routledge, (Chapter III).

Njagi, M.W. \& Muriungi, C.K. (2014). Effectiveness of professional development on English and literature teachers in selected schools in Tharaka-Nithi and Meru County, Kenya. American International Journal of Contemporary Research, 4 (8), 142-148.

Novianti, N. (2016). English Literature Teaching: an Indonesian Context. Indonesian Journal of Applied Linguistics. 6 (1), 42-49. doi: dx.doi.org/10.17509/ijal.v6il.2660.

Nurgiyantoro, B., \& Efendi, A. (2013). Prioritas penentuan nilai pendidikan karakter dalam pembelajaran sastra remaja. Cakrawala Pendidikan, XXXII (3), 382-393.

Ortells, E. (2013). Teaching English as a foreign language in Spanish secondary schools: The value of literature. English Teaching: Practice and Critique, 12 (1), 91-110.

Qiping, Y. \& Shuba, C. (2002). Teaching English literature in China: Importance, problems and countermeasures. World Englishes, 21 (20), 317-324.

Rashid, R.A., Vethamani, M.E., \& Rahman, S.B.A. (2010). Approaches employed by teachers in teaching literature to less proficient students in form 1 and form 2. English Language Teaching, 3 (4), 87-99.

Rohmah, Z. (2012). Incorporating Islamic messages in the English teaching in the Indonesian context. International J. Soc. Sci. \& Education, 2 (2), 157-165.

Samuel, M. (1995). Learning and teaching literature: A curriculum development perspective. Alteration, 2 (1), 94-107.

Shakfa, M.D.A.(2012). Difficulties Students Face in Understanding Drama in English Literature at the Islamic University of Gaza (IUG). English Language Teaching. 5 (9), 95-103. doi: 10.5539/elt.v5n9p95, http://dx.doi. org/10.5539/elt.v5n9p95.

Stern, S.L. (1991). An integrated approach to literature in ESL/EFL. In Celce-Murcia, M. (ed.), Teaching English as a second or foreign language ( $\left.2^{\text {nd }} e d\right)$ (pp. 328-346). Boston: Heinle \& Heinle Publishers, (Chapter III).

Tuncer, H. \& Kizildağ, A. (2014). Pre-service EFL teachers' attitude towards the use of literature in practice teaching. International Journal of Language Academy, 2 (3), $170-185$

Violetta-Irene, K. (2015). The use of literature in the language classroom: Methods and aims. International Journal of Information and Education Technology, 5 (1), 74-79. doi: 10.776/IJIET.2015.V5.479

Yeasmin, N. (2011). Prospects of teaching and learning English literature in Bangladesh: Background vs the current status and some recommendations. American Academic \& Scholarly Research Journal, 1 (1), 10-20. 
Yeasmin, N., Azad, M.A.K., \& Ferdoush, J. (2011). Teaching language through literature: Designing appropriate classroom activities. ASA University Review, 5 (2), 283-297.

Yimwilai, S. (2015). An integrated approach to teaching literature in an EFL classroom. English Language Teaching, 8 (2), 14-21.

Zainal, A. (2012). ESL Teachers' Use of ICT in Teaching
English Literature: an Analysis of Teachers' TPCK. Procedia-Social and Behavioral Sciences. 34 (2012), 234237. doi: 10.1016/j.sbspro.2012.02.047.

Zhen, C. (2012). Characteristics and strategies of literature teaching in the EFL context in China. International Journal of Electronics and Communication Engineering, 5 (3), 35-43.

Author Queries???

AQ1: Kindly check table caption

AQ2: Kindly cite table 8,9 and 10 